\title{
Eutrophication and occurrences of harmful algal blooms in the Seto Inland Sea, Japan
}

\author{
ICHIRO IMAI $^{1 *}$, MineO YAMAGUCHI ${ }^{2} \&$ YUTAKA HORI ${ }^{3}$ \\ ${ }^{1}$ Laboratory of Conservation of Coastal Ecosystems, Graduate School of Global Environmental Studies (concurrent with \\ Laboratory of Marine Environmental Microbiology, Division of Applied Biosciences, Graduate School of Agriculture) Kyoto \\ University, Kyoto 606-8502, Japan \\ ${ }^{2}$ Red Tide Research Division, National Research Institute of Fisheries and Environments of Inland Sea, Maruishi, Hatsukaichi, \\ Hiroshima 739-0452, Japan \\ ${ }^{3}$ Fisheries Technology Institute, Hyogo Prefectural Technology Center for Agriculture, Forestry and Fisheries, Futami, Akashi, \\ Hyogo 674-0093, Japan
}

Received 28 February 2006; Accepted 10 April 2006

\begin{abstract}
The Seto Inland Sea is the largest enclosed coastal sea in Japan and is also a major fishing ground including aquacultures of fish, bivalves and seaweeds. The incidents of red tides dramatically increased in frequency and scale in the Seto Inland Sea along with serious eutrophication in the 1960s and 1970s. The maximum incident of 299 was recorded in 1976, but the incident has since shown a clear decreasing trend, reaching about 100 per year in the late 1980 s by virtue of regulation by law, and this level has been maintained thereafter with the level of nutrients supporting red tide occurrences. The "Law Concerning Special Measures for Conservation of the Environment of the Seto Inland Sea" was legislated in 1973 and industrial loading was decreased to half the level of 1972. The important red tide organisms causing huge fishery damages by fish-kill are Chattonella antiqua, C. marina, C. ovata and Heterosigma akashiwo (Raphidophyceae), and Karenia mikimotoi and Cochlodinium polykrikoides (Dinophyceae). The maximum fishery damage (death of 14.2 million yellowtails) was 7.1 billion yen (about US $\$ 60$ million) caused by C. antiqua in Harima-Nada in 1972. In 1988, a novel red-tide dinoflagellate species Heterocapsa circularisquama appeared for the first time, and has repeatedly killed both natural and aquacultured bivalves, with the highest damage of 3.9 billion yen to cultured oysters in Hiroshima Bay in 1998. Among the important red-tide organisms, C. antiqua, H. circularisquama and C. polykrikoides are rated as extremely harmful species that can easily reach the warning level of fishery damage by consuming only small amounts of nutrients. In toxic blooms, the dinoflagellate Alexandrium tamarense has become dominant in the Seto Inland Sea in the spring season, causing toxicity in short-necked clams and cultured oysters almost every year. Many countermeasures have been applied for harmful algal blooms in Japan. Laws for the regulation of water quality have been most effective in decreasing red-tide occurrences. No physical and chemical controls have been successful except for clay treatments. Clay spraying has been investigated and implemented in Kyushu and Korea for the removal of $C$. polykrikoides red tides. As environment-friendly mitigation strategies for red tides, biological controls using algicidal bacteria and viruses are proposed. A new finding of the abundant existence of algicidal bacteria on the surface of seaweeds suggests that co-culturing fish and seaweed is a prevention strategy for harmful algal blooms by virtue of the continuous release of many algicidal bacteria to the surrounding seawater. The artificial development of seaweed beds would also be effective as a prevention strategy for red tides.
\end{abstract}

Key words: Harmful algal blooms, red tides, fish-kill, toxic blooms, Seto Inland Sea, eutrophication, fishery damage, mitigation, algicidal bacteria, viruses, seaweeds

\section{Introduction}

The Seto Inland Sea is the largest enclosed coastal sea with many islands surrounded by Honshu, Kyushu and

* Corresponding author: Ichiro Imai; E-mail, imai1ro@kais.kyoto-u.ac.jp
Shikoku in Japan (Fig. 1), and was first designated as "Seto Inland Sea National Park" in 1934 by virtue of the elegant and beautiful scenery stretching over a wide area. Most of the area is less than $50 \mathrm{~m}$ deep (mean depth, $38 \mathrm{~m}$ ). The Seto Inland Sea covers an area of about $2.3 \times 10^{4} \mathrm{~km}^{2}$ and holds about $8.8 \times 10^{11} \mathrm{~m}^{3}$ of seawater (Table 1). The climate 


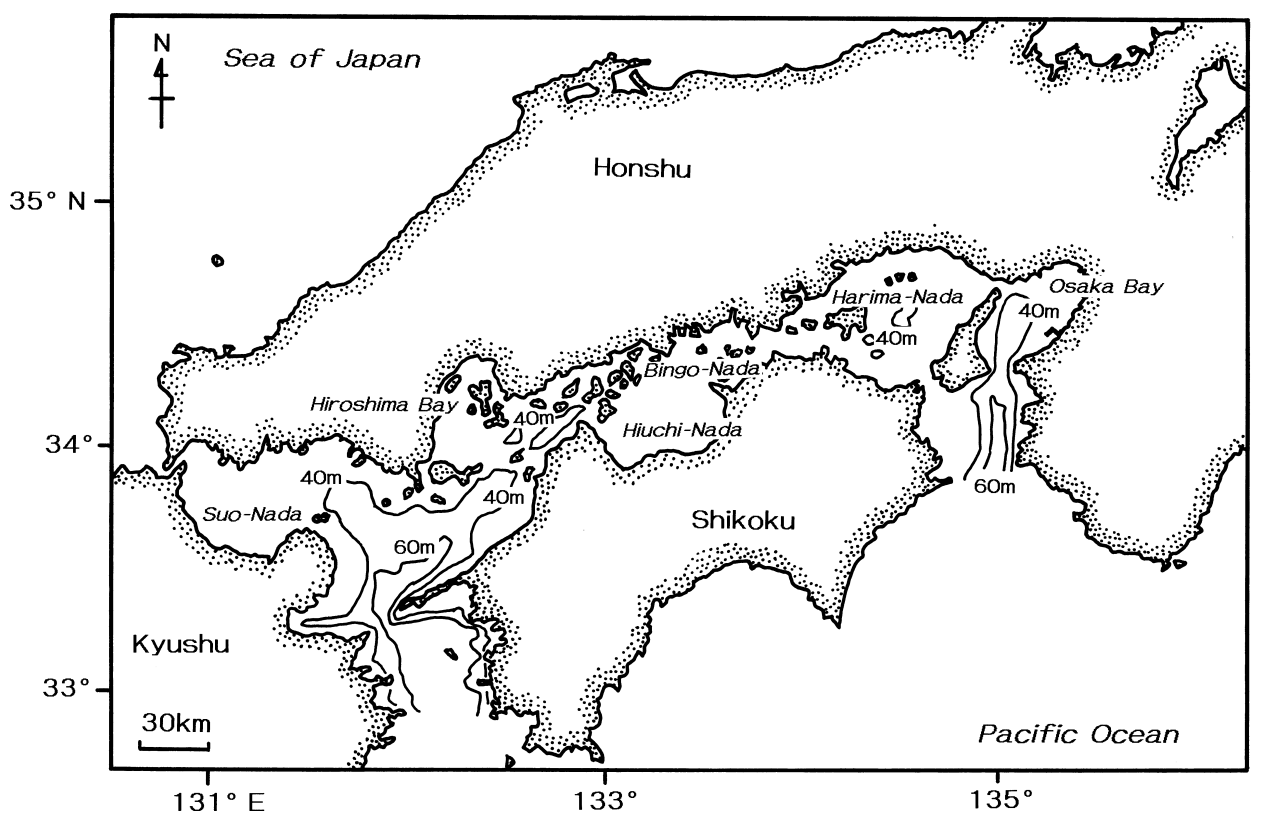

Fig. 1. The Seto Inland Sea.

Table 1. Characteristics of the Seto Inland Sea, Japan

\begin{tabular}{lc}
\hline Area & $23203 \mathrm{~km}^{2}$ \\
Mean depth & $38 \mathrm{~m}$ \\
Volume & $8.8 \times 10^{11} \mathrm{~m}^{3}$ \\
Islands & 1015 \\
Precipitation & $1000-1600 \mathrm{~mm} \mathrm{yr}^{-1}$ \\
River (class A and B) & 664 \\
Run off & $5.0 \times 10^{10} \mathrm{~m}^{3} \mathrm{yr}-1$ \\
Water temperature & $8-26^{\circ} \mathrm{C}$ \\
Population & $3.0 \times 10^{7}$ \\
Fishery production & $6 \times 10^{5}{\text { ton } \mathrm{yr}^{-1}}^{-1}$ \\
Aquaculture production & $3 \times 10^{5}$ ton $\mathrm{yr}^{-1}$ \\
\hline
\end{tabular}

is mild with an average temperature of about $15^{\circ} \mathrm{C}$. The coastal regions bordering the Seto Inland Sea (12\% area of Japan) are inhabited by about 30 million people, about $24 \%$ of the total population of Japan. The Seto Inland Sea receives water from 664 rivers (class $A$ and B), and $5 \times 10^{10} \mathrm{~m}^{3}$ water flows into the sea every year. Osaka Bay, northern Harima-Nada and northern Hiroshima Bay are the heavily eutrophicated areas with dense populations and heavy run off through big rivers.

The Seto Inland Sea is a major fishing ground with a yearly total production of about $6 \times 10^{5}$ tons in recent years. Aquaculture production by the cultivation of fish, bivalves and seaweeds regularly occupies about half of the total fishery production. This is a characteristic point of fisheries in the Seto Inland Sea. Many red-tide incidents have recurred in the Seto Inland Sea, and have caused serious fishery damage to cultured fish and bivalves in aquacultures (Iwasaki 1989, Okaichi 1997, Imai et al. 1998b). Here we describe the history of eutrophication and the occurrence of harmful algal blooms, discuss the characteristics of repre- sentative red-tide organisms in the Seto Inland Sea, and summarize the current situation of countermeasures for red tides and mitigation strategies, especially using microorganisms.

\section{History of eutrophication}

In the 1960s, the coastal region of the Seto Inland Sea played a leading role in contributing to the explosive economic growth of Japan, resulting in extremely heavy amounts of pollutants and serious eutrophication. Figure 2 shows the pollutant loads of COD (Chemical Oxygen Demand), total phosphorus and total nitrogen in the Seto Inland Sea. In 1973, the "Law Concerning Special Measures for Conservation of the Environment of the Seto Inland Sea" was enacted, and "Total Pollutant Load Control" was established to reduce the total quantity of organic pollutants in terms of COD from factories, sewage treatment plants, etc. The enactment of this law was triggered by a red tide of Chattonella antiqua (Hada) Ono, which caused the largest economic loss by the mass mortality of cultured yellowtails ( 7.1 billion yen) in the summer of 1972. As a result of this law, the quantity of COD dumped in the Seto Inland Sea, which was 1700 tons per day in 1972, had been reduced to 717 tons per day by 1999 (Ministry of the Environment Government of Japan \& the Association for the Environmental Conservation of the Seto Inland Sea 2001). In the case of total-P, total load control was implemented from 1979, and loading has actually decreased (Fig. 2). Effluent control of total-N was established in 1996, and the loaded $\mathrm{N}$ was also reduced in 1999 (Fig. 2).

The long-term monthly monitoring of water quality has continued by the Fisheries Technology Institute, Hyogo Prefecture, in the northeastern half of Harima-Nada (21 stations) since 1973 (Manabe et al. 1994). Figure 3 shows 

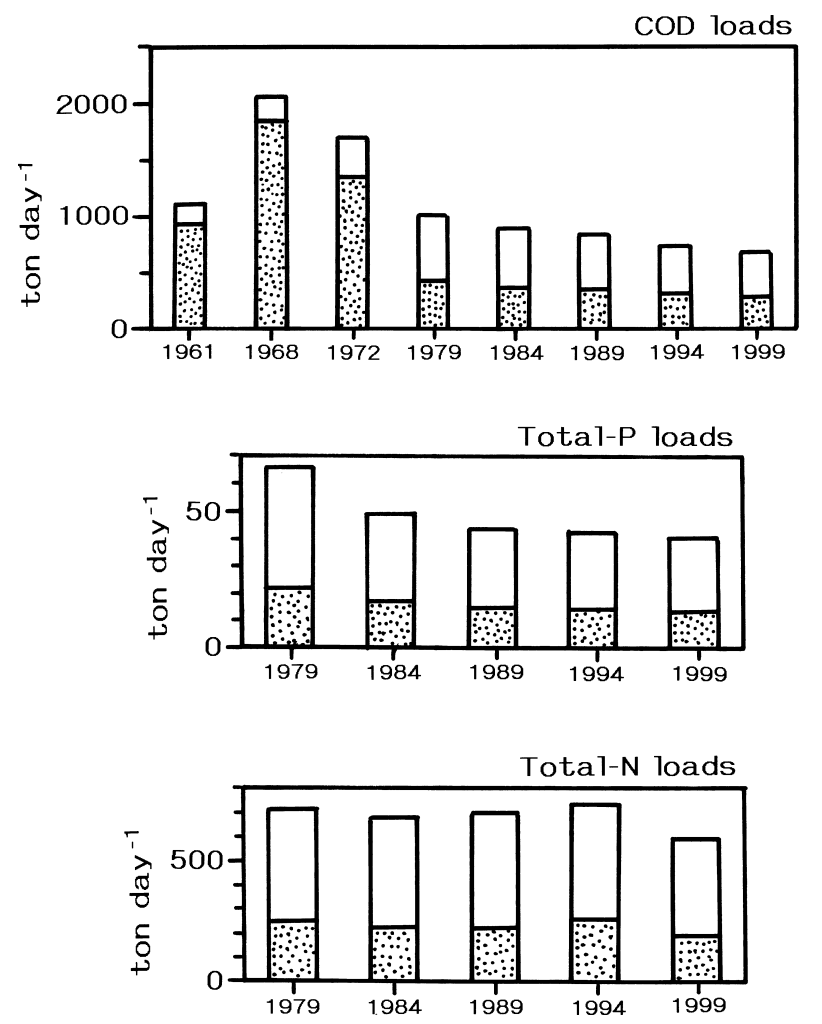

Fig. 2. Pollutant loads of COD, phosphorus, and nitrogen in the Seto Inland Sea. Open columns show the loads from households and others, and dotted columns show the industrial loads (from the Ministry of the Environment Government of Japan \& the Association for the Environmental Conservation of the Seto Inland Sea 2001).

long-term changes in $\mathrm{COD}$ and inorganic nutrients $\left(\mathrm{NH}_{4}-\mathrm{N}\right.$, $\mathrm{NO}_{2}-\mathrm{N}, \mathrm{NO}_{3}-\mathrm{N}, \mathrm{DIN}, \mathrm{PO}_{4}-\mathrm{P}, \mathrm{SiO}_{2}-\mathrm{Si}$ ). COD had decreased from $2.5 \mathrm{mg} \mathrm{L}^{-1}$ or higher to about $1 \mathrm{mg} \mathrm{L}^{-1}$ by 1985 and has remained around this level. Ammonium (NH4-N) also decreased and has remained at a low level. Dissolved inorganic nitrogen (DIN: $\mathrm{NH}_{4}-\mathrm{N}+\mathrm{NO}_{2}-\mathrm{N}+\mathrm{NO}_{3}-\mathrm{N}$ ) generally showed a decreasing tendency from 1973 to 1984 , and has since remained at around $4 \mu \mathrm{M}$ in the surface and middle $(10 \mathrm{~m})$ layers. Phosphate $\left(\mathrm{PO}_{4}-\mathrm{P}\right)$ also showed a decreasing tendency to 1984 , gradual increasing to 1992 , remaining at a stable level of around $0.4 \mu \mathrm{M}$ in the surface and middle layers until today. The $\mathrm{SiO}_{2}$-Si level of the surface and middle $(10 \mathrm{~m})$ layers has shown no general tendency and fluctuated between about 5 and $10 \mu \mathrm{M}$, and that of the bottom layer fluctuated between about 10 and $15 \mu \mathrm{M}$.

\section{Harmful algal blooms}

In eutrophicated coastal areas, microalgal populations grow densely and sometimes form algal blooms with water discoloration. Some microalgal species have a negative effect on marine organisms as a result of bloom formation. These microalgae are called "harmful algae", and the phenomena of increasing populations of harmful algae are designated as harmful algal blooms (HABs) (Hallegraeff

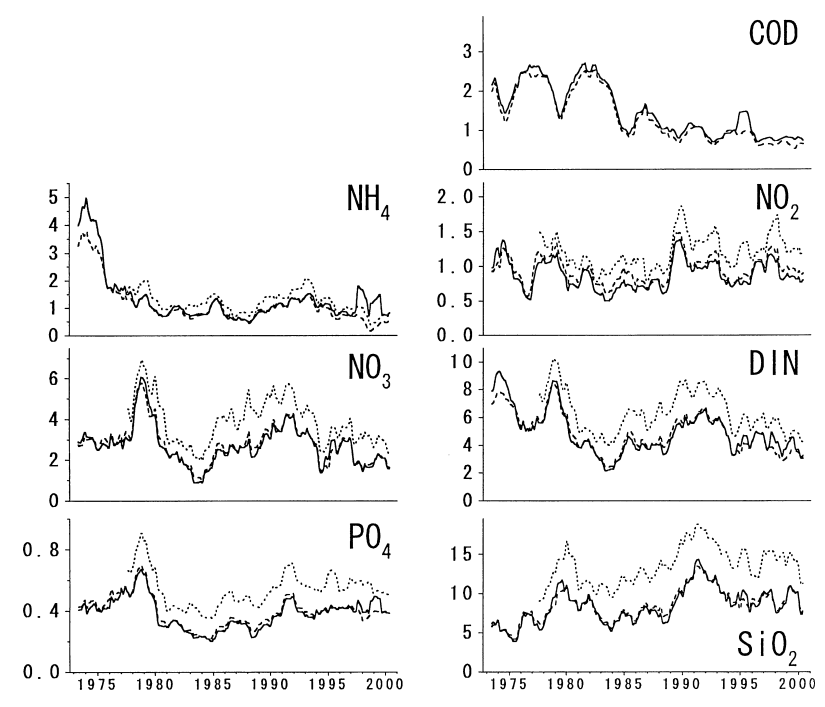

Fig. 3. Long-term changes in $\operatorname{COD}\left(\mathrm{mgL}^{-1}\right)$ and nutrients $(\mu \mathrm{M})$ in the north-eastern part of Harima-Nada, the Seto Inland Sea (solid lines: surface, dashed lines: $10 \mathrm{~m}$, dotted lines: bottom) from April 1973 to March 2000. Data were treated by 12-month moving average process.

1993). Four types of HABs are summarized in Table 2. Biomass blooms are composed of basically non-toxic species; however, blooms can grow so dense that they indiscriminately kill fish and invertebrates due to oxygen depletion as a result of decomposition (Hallegraeff 1993). In toxic blooms, their potent toxins are accumulated mainly in bivalves through the food chain, and those toxins cause a variety of gastrointestinal and neurological illnesses in humans by the consumption of toxin-contaminated bivalves. Shellfish poisoning can occur under low cell densities of toxic species without water discoloration. Noxious red tides are non-toxic to humans, but harmful to fish and invertebrates causing mass mortalities, especially in intensive aquaculture in coastal areas. Diatom blooms have a negative impact on "Nori" (Porphyra, red alga) aquaculture in coastal areas between autumn and spring by bleaching Porphyra thalli, which lowers the quality and price of Nori products (Manabe \& Ishio 1991, Nagai 2000). Since Nori is a big aquaculture industry in Japan, diatom blooms are an economically nuisance in Nori aquaculture areas during the seaweed-growing season. It is very difficult to estimate the fishery damage (monetary amount) of Nori bleaching in aquaculture by diatom blooms and of bivalve aquaculture harvest regulation due to toxic blooms. In the Seto inland Sea, eutrophication is closely linked to red tides especially of noxious and biomass bloom types.

\section{Red-tide occurrences and fishery damages}

In 1960 and 1965, the beginning of the high-growth period of Japanese economy, the total incident of red-tide occurrences was less than 50 per year in the Seto Inland Sea (Okaichi 1997). Figure 4 represents the occurrences of red 
Table 2. Types of harmful algal blooms in the coastal sea (after Hallegraeff 1993, modified by adding diatom blooms against Porphyra aquaculture).

1) Biomass red tides (Biomass blooms): Biomass red tides are basically harmless water discolorations; however, they sometimes become so dense under exceptional conditions that they indiscriminately kill fish and invertebrates due to oxygen depletion.

Causative species: Gonyaulax polygramma, Noctiluca scintillans, Scrippsiella trochoidea, Trichodesmium erythraeum

2) Toxic blooms: Toxic blooms cause shellfish poisoning and fishfood poisoning as a result of the accumulation of toxins contained in microalgae through the food chain. Low cell densities $\left(<1\right.$ cell $\left.\mathrm{mL}^{-1}\right)$ can bring about shellfish poisoning.

Poisoning and causative species

-Paralytic Shellfish Poisoning (PSP): Alexandrium tamarense, A. catenella, A. tamiyavanichii, A. minutum, Gymnodinium catenatum, Pyrodinium bahamense var. compressum

-Diarrhetic Shellfish Poisoning (DSP): Dinophysis fortii, D. acuminata, D. caudata, D. mitra, D. rotundata, Prorocentrum lima

-Amnesic Shellfish Poisoning (ASP): Pseudo-nitzschia multiseries, P. australis, P. delicatissima

-Neurotoxic Shellfish Poisoning (NSP): Karenia brevis

-Ciguatera Fishfood Poisoning: Gambierdiscus toxicus

3) Noxious red tides: Red tides of this type are non-toxic to humans, but harmful to fish and invertebrates, especially in intensive aquaculture sites, causing mass mortalities.

Causative species: Chattonella antiqua, C. marina, C. ovata, C. verruculosa, Heterosigma akashiwo, Heterocapsa circularisquama, Karenia mikimotoi, Cochlodinium polykrikoides, Chrysochromulina polylepis, Prymnesium parvum

4) Diatom blooms: Diatoms are usually important as primary producers; however, diatom blooms have a negative impact on 'Nori' (Porphyra) aquaculture between autumn and spring by bleaching Porphyra thalli, which lowers the quality and price of Nori products.

Causative species: Eucampia zodiacus, Coscinodiscus wailesii, Chaetoceros spp., Skeletonema costatum, Thalassiosira spp., Rhizosolenia imbricata

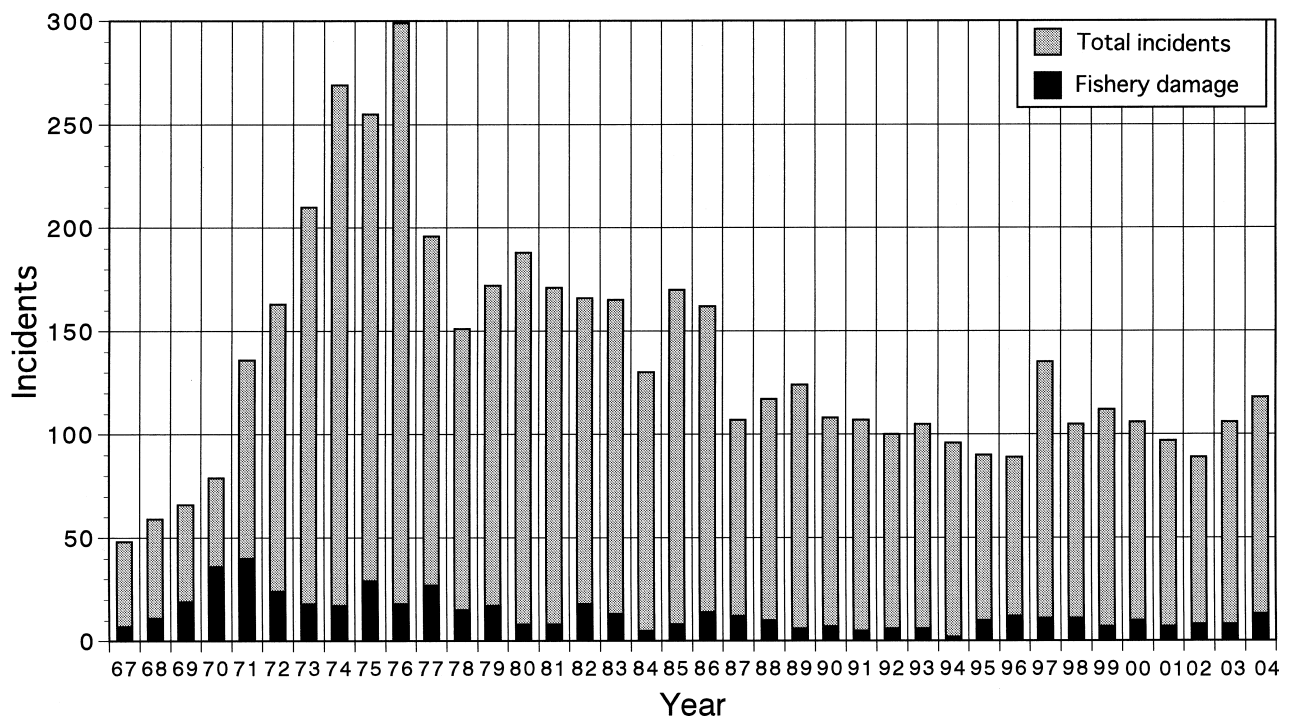

Fig. 4. Occurrence of red tides in the Seto Inland Sea from 1967 to 2004. Closed columns indicate incidents with fishery damage such as fish-kills.

tides (incidents per year) in the Seto Inland Sea from 1967 to 2004 (Fisheries Agency of Japan 2000, 2005). The total incident was 48 in 1967, showing a clear increment to the maximum value of 299 per year in 1976. The law for environmental conservation for the Seto Inland Sea was enacted in 1973 as mentioned previously. After the peak in 1976, the incident showed a clear decreasing trend to around 100 per year, and this level has been maintained so far.

The distribution of red-tide areas in the Seto Inland Sea from 1960 to 2000 is decennially shown in Fig. 5. In 1960, there were few red-tide incidents (18 cases), and the areal scale was small. In the 1970s and 1980s, large-scale red tides had frequently occurred, especially in the summer season. In extreme cases, a red tide covered almost the whole area of the sea, such as Osaka Bay, Harima-Nada, HiuchiNada, and Suo-Nada. In the 1990s and thereafter, the scale and period of red tides appeared to become smaller and shorter except for a novel and peculiar dinoflagellate 


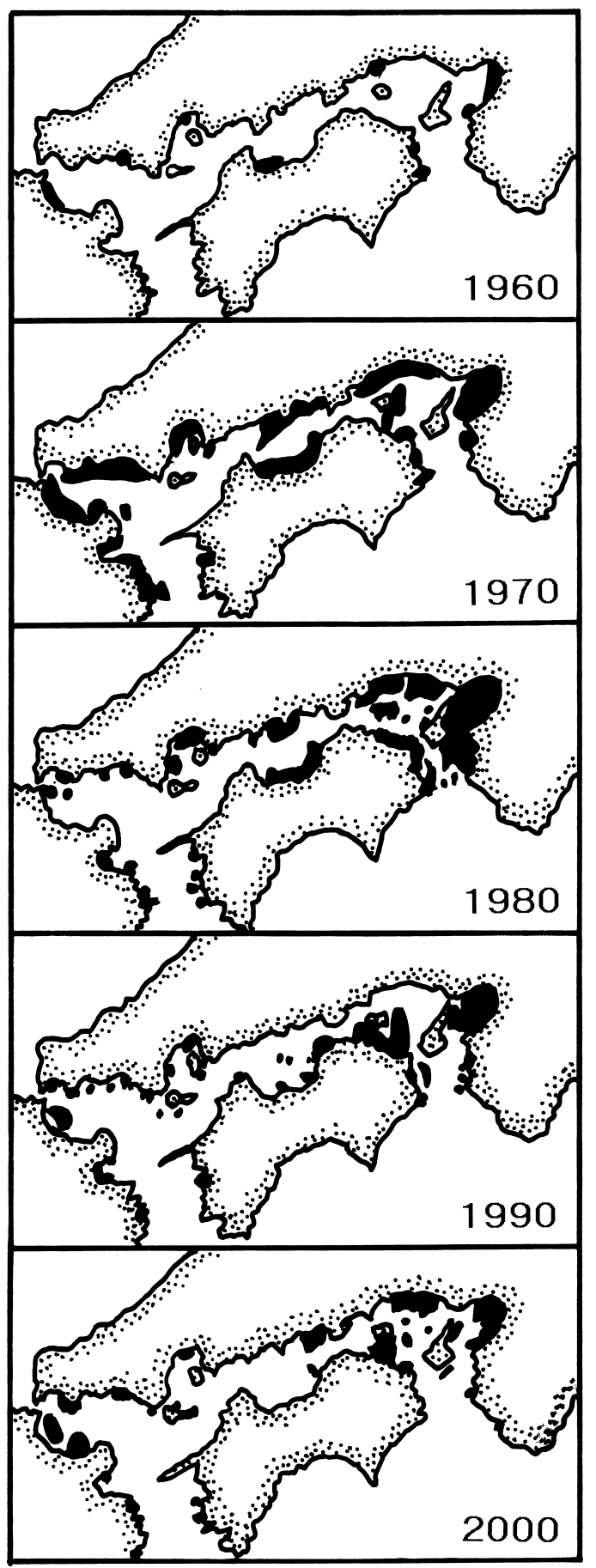

Fig. 5. Decadal changes in the distribution of red-tide areas in the Seto Inland Sea.

species (Heterocapsa circularisquama Horiguchi, later in detail).

The representative organisms of noxious red tides in the Seto Inland Sea are Chattonella antiqua, Chattonella marina (Subrahmanyan) Hara et Chihara, Chattonella ovata Hara et Chihara, Heterosigma akashiwo (Hada) Hada ex Hara et Chihara (Raphidophyceae), Noctiluca scintillans (Macartney) Kofoid, Karenia mikimotoi (Miyake et Komi-
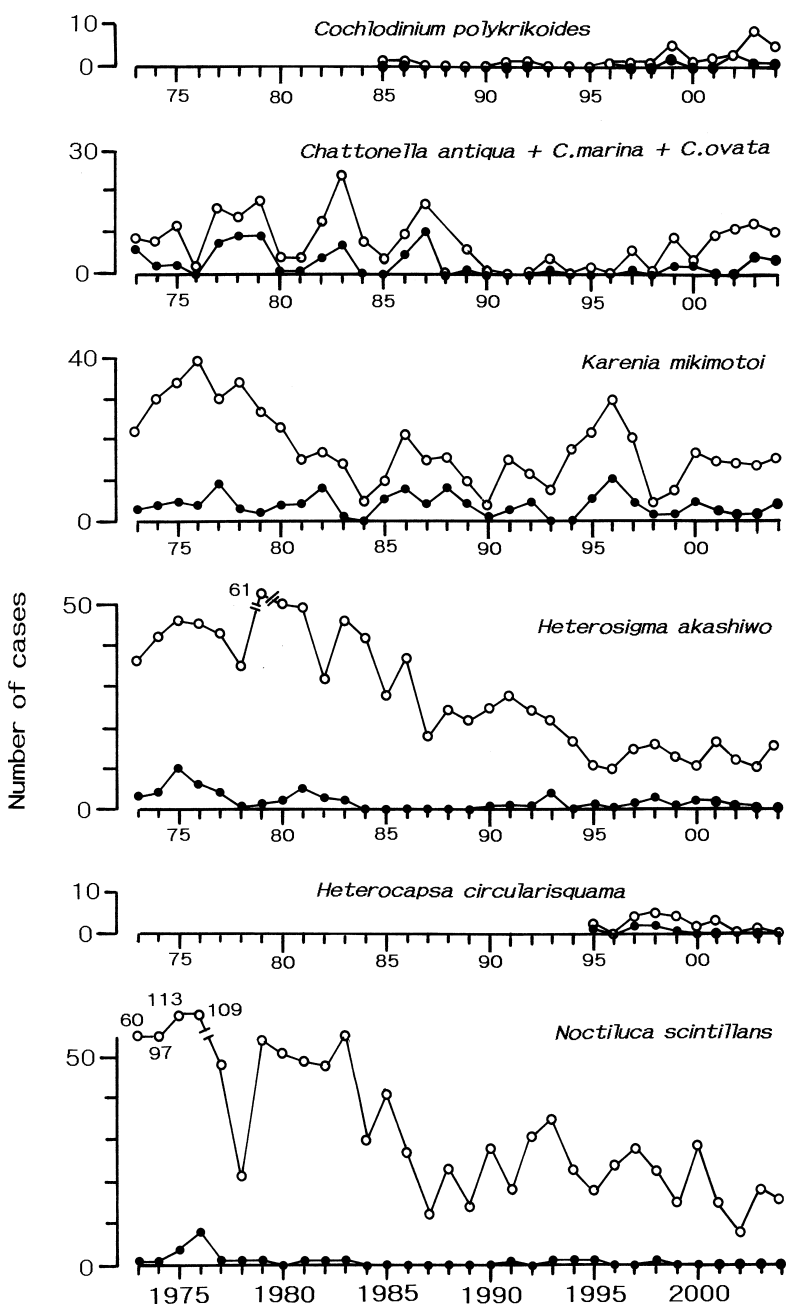

Fig. 6. Number of red tides (open circle) and those with fishery damage (closed circle) caused by Cochlodinium polykrikoides, Chattonella spp., Karenia mikimotoi, Heterosigma akashiwo, Heterocapsa circularisquama, and Noctiluca scintillans in the Seto Inland Sea from 1973 to 2004.

nami ex Oda) Hansen et Moestrup, Cochlodinium polykrikoides Margalef and $H$. circularisquama (Dinophyceae). The top three most noxious species in the order corresponding to the amount of fishery damage are $C$. antiqua, K. mikimotoi and H. circularisquama in the Seto Inland Sea. Figure 6 illustrates the number of red tides and those with fishery damage caused by the red-tide organisms mentioned above from 1973 to 2004, according to the data of the Fisheries Agency of Japan (2000, 2005). Karenia mikimotoi, $H$. akashiwo and $N$. scintillans showed a high number of red-tide occurrences in the Seto Inland Sea in the 1970s; however, these species decreased in incident thereafter. Red tides of $C$. antiqua and C. marina were commonly observed in the 1970s and 1980s, but they decreased in the 1990s and thereafter; however, Chattonella red tides have shown a reviving trend in recent years, newly joining $C$. ovata. The long-term and general trend is decreasing tendency except for $H$. circularisquama, which 


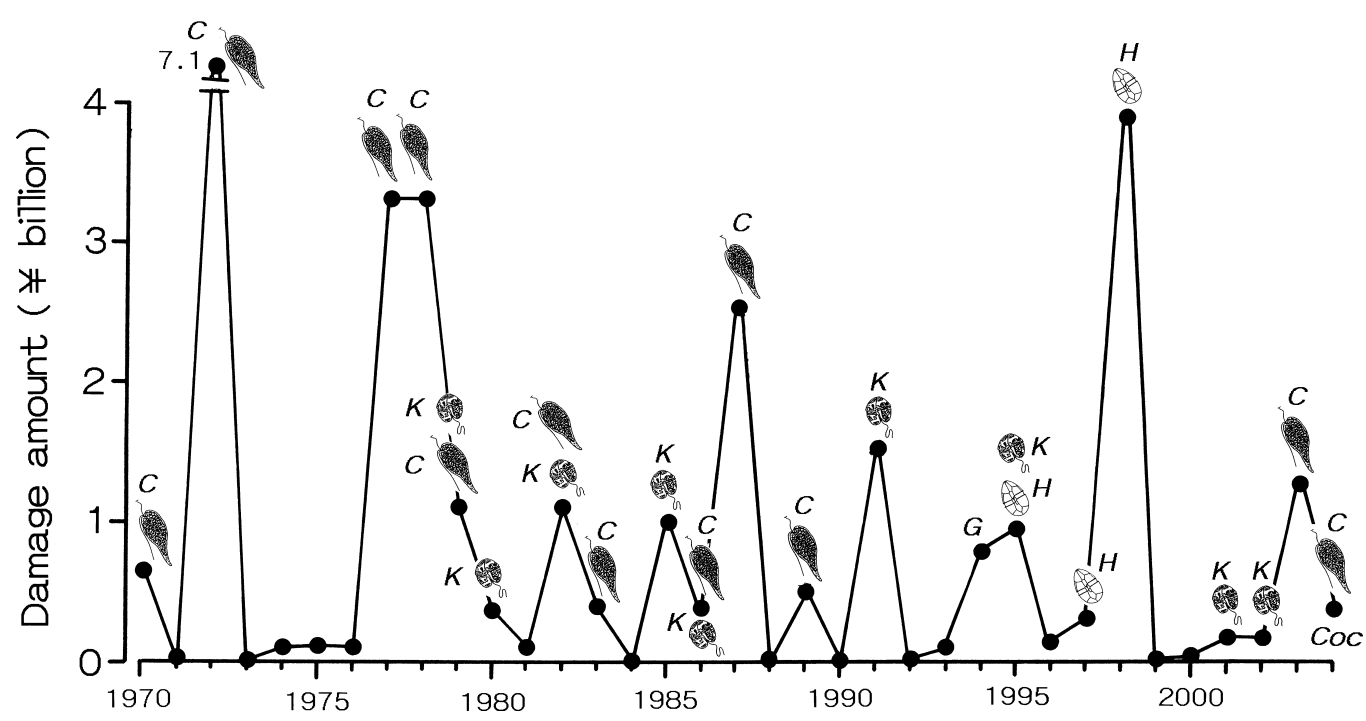

Fig. 7. Fishery damage to aquaculture caused by noxious red tides in the Seto Inland Sea from 1970 to 2004 . Illustrations indicate causative microalgae responsible for $>80 \%$ of total damage of each year. C: Chattonella spp. (C. antiqua, C. marina and $C$. ovata), K: Karenia mikimotoi, H: Heterocapsa circularisquama, G: Gonyaulax polygramma, Coc: Cochlodinium polykrikoides.

was first detected in 1995 in the Seto Inland Sea (Hiroshima Bay), although this species caused the first red tide in 1988 in Uranouchi Inlet, Pacific coast of Shikoku. Red tides of C. polykrikoides have appeared to increase in recent years, although there are only 5 incidents per year or lower. In the Seto Inland Sea, a bloom of this species was first noticed in Harima-Nada in 1985 (Yuki \& Yoshimatsu 1989). Heterosigma akashiwo and N. scintillans form red tides more frequently but rarely cause fishery damage in general. On the other hand, red tides of Chattonella spp. ( $C$. antiqua, C. marina and C. ovata), K. mikimotoi, H. circularisquama and C. polykrikoides tend to accompany fishery damage more frequently.

Figure 7 represents fishery damage to aquaculture from 1970 to 2004 caused by noxious red tides and the causative organisms responsible for $>80 \%$ damage of each year in the Seto Inland Sea according to data from the Fisheries Agency $(2000,2005)$. Chattonella spp. (C. antiqua, C. marina and $C$. ovata) are the most harmful red-tide organisms as indicated by Fig. 7. In the summer of 1972, C. antiqua killed 14.2 million cultured yellowtails, worth about 7.1 billion yen in Harima-Nada, which is the worst record in Japan. During the period between 1990 and 2002, fishery damage by Chattonella was lower than 0.1 billion yen per year, but Chattonella red tides revived to make fish-kill in the Seto Inland Sea in 2003 and 2004. Karenia mikimotoi has continuously caused fishery damages since 1979 in the Seto Inland Sea. The killing of oysters in the Seto Inland Sea by the dinoflagellate $H$. circularisquama first occurred in Hiroshima Bay in 1995, and again in 1997. Heterocapsa circularisquama caused the mass mortality of oysters worth 3.9 billion yen in 1998 in Hiroshima Bay, which was the second worst fishery damage in the Seto Inland Sea. As a long-term trend, however, the total damage amounts appear to be showing a decreasing tendency except for the 1998 case by $H$. circularisquama. A red tide by the dinoflagellate Gonyaulax polygramma Stein in 1994 is a case with a large fishery damage of 0.8 billion yen in the Seto Inland Sea (Koizumi et al. 1996a). Fish-kills by C. polykrikoides have been observed in the Seto Inland Sea since 1985 (Yuki \& Yoshimatsu 1989), but the damage and red-tide scales have been smaller than those by other species; however in the summer of 2004, fish-kills by C. polykrikoides first exceeded 0.1 billion yen ( 0.16 billion yen) in Iwamatsu Bay in Ehime Prefecture in Bungo Channel, the Seto Inland Sea (Fisheries Agency 2005). This species is notorious for the immense harmfulness of its fish-kills in the Kyushu area (the largest damage of 4 billion yen in Yatsushiro Sea in the summer of 2000) and especially in Korean coastal waters (largest damage of 76.4 billion won in the summer of 1995 , Yoon 2001, Kim et al. 2002), and hence more attention should be paid to monitoring C. polykrikoides in the Seto Inland Sea.

\section{Characteristics of representative red-tide organisms}

Table 3 shows the first detection of red tides and notes on the origin of the five main red-tide organisms in the Japanese coastal sea. Chattonella spp. (C. antiqua, C. marina and C. ovata) have a cyst stage in their life cycle (Imai \& Itoh 1986, 1987, 1988, Yamaguchi et al. personal communication about C. ovata). Empty cysts of Chattonella spp. can be commonly observed by the primulin-staining method (Yamaguchi et al. 1995) from deep sediments from 1950 or before (Montani 2000). This is before the eutrophication period, or the high-growth period of the Japanese economy; 
Table 3. First occurrences of red tides and notes on the origin of the representative red-tide organisms in the Japanese coastal sea.

\begin{tabular}{lll}
\hline \multicolumn{1}{c}{ Speceis } & \multicolumn{1}{c}{ First red tide (year) } & \multicolumn{1}{c}{ Notes } \\
\hline $\begin{array}{l}\text { Chattonella antiqua } \\
\text { Karenia mikimotoi }\end{array}$ & Hiroshima Bay (1969) & Hidden flora* \\
& Ago Bay, Gokasho Bay (1933) & Inherent red-tide species \\
Teterosigma akashiwo & Bingo-Nada (1966) & Hidden flora \\
Heterocapsa circularisquama & Uranouchi Inlet (1988) & Introduced species (?) \\
Cochlodinium polykrikoides & Yatsushiro Sea (1975) & Hidden flora and/or transported species by Tsushima Current \\
\hline
\end{tabular}

* These species have inhabited at low cell densities before the occurrence of red tide (Smayda 2002).

therefore, Chattonella spp. are considered to be originally "hidden flora" (Smayda 2002), which have usually inhabited at low cell densities since ancient times.

Heterosigma akashiwo is a cosmopolitan species in coastal areas of temperate and subtropical countries (Honjo 1992, Smayda 1998). It has a cyst stage in its life cycle (Imai et al. 1993b, Imai \& Itakura 1999); hence, $H$. akashiwo also appears to be originally a "hidden flora" species. In the case of Karenia mikimotoi, it has the first report of red tide in Gokasho Bay in Mie Prefecture, a Pacific coastal embayment, in 1933, and in Tokuyama Bay, the Seto Inland Sea, in 1957. Since K. mikimotoi formed noxious red tides recurrently before the eutrophication period, this organism is considered to be an inherent red-tide species from ancient times.

The first red tide of the bivalve-killer dinoflagellate Heterocapsa circularisquama was recorded in Uranouchi-Inlet in 1988, and then in Fukuoka Bay in 1989 and in Ago Bay in 1992 (Tamai 1999). These three embayments are not in the Seto Inland Sea. Overwintering cysts have not been identified yet. For this dinoflagellate, winter temperatures of less than $15^{\circ} \mathrm{C}$ in the Seto Inland Sea and most of the Japanese coastal sea are too low for this species to overwinter (Yamaguchi et al. 1997); however, Shiraishi et al. (in preparation) recently discovered $H$. circularisquama overwintering as motile vegetative cells in Uranouchi-Inlet, Pacific coast of Kochi Prefecture. This species forms resistant temporary cysts, and can be transferred with commercially useful bivalves (Honjo et al. 1998). Recently, Iwataki et al. (2002) reported new records of $H$. circularisquama in Hong Kong, which caused red tides in 1986 and 1987. Therefore, this species is suspected to have originally inhabited tropical coastal areas, and to have been introduced into the Japanese coastal sea by warm currents and/or by the artificial transportation of pearl oysters and short-necked clams for aquaculture (Matsuyama 1999).

Cochlodinium polykrikoides was reported to form the first red tide to kill fish in the Yatsushiro Sea, western Kyushu, in the summer of 1975 (Kumamoto Prefecture 1980). The growth response of $C$. polykrikoides was examined in different combinations of temperature and salinity (Kim et al. 2004, Yamatogi et al. 2005, 2006). This species prefers high temperature and salinity for optimum growth; however, this alga exhibited some growth even at a temper- ature of $10^{\circ} \mathrm{C}$ (Yamatogi et al. 2005, 2006). The lowest water temperature is usually higher than $10^{\circ} \mathrm{C}$ in the coastal waters of the south and west parts of Japan. Consequently, C. polykrikoides might be able to overwinter in those coastal areas, implying that this dinoflagellate was a "hidden flora" and began to cause red tides and kill cultured fish in 1975. Matsuoka \& Iwataki (2004) pointed out the two type patterns of red-tide formation of this microalga: one is the Tsushima Current-introducing pattern in western Kyushu areas and the coast of the Sea of Japan, and the other is the independent-occurrence pattern in the Seto Inland Sea and Pacific coasts of Kyushu, Shikoku and Honshu. In the former case, Miyahara et al. (2005) reported small-scale red tides of $C$. polykrikoides along the coast of the Sea of Japan such as Tottori and Hyogo Prefectures in September 2003, and strongly suggested that seed populations of this microalga were transported to those coastal areas by the Tsushima Current based on the image analyses of water temperature and chlorophyll a by satellite observations. Consequently, two types of occurrence mechanisms should be considered for C. polykrikoides red tides.

Yamaguchi et al. (2001) summarized the minimum cell quota for $\mathrm{N}$ and $\mathrm{P}$, and their ratios concerning important red-tide flagellates $C$. antiqua, $K$. mikimotoi, $H$. akashiwo and $H$. circularisquama. In the case of $C$. polykrikoides, Kim (2003) reported the minimum cell quota of $N$ and $P$. In order to evaluate the degree of danger and harm of these five representative red-tide species, the warning levels of cell densities of $C$. polykrikoides and four other species (Hiroshima Prefecture 1996) were converted to equivalent levels of nitrogen and phosphorus (Table 4). The warning cell density level of $C$. polykrikoides was tentatively determined to be 500 cells $\mathrm{mL}^{-1}$, according to the warning level of Nagasaki Prefecture and the record of fish-killing at a cell density of 221 cells $\mathrm{mL}^{-1}$ (Kim 2003). Karenia mikimotoi and $H$. akashiwo needed rather high amounts of $\mathrm{N}$ and $\mathrm{P}$ to reach the warning levels; however, the diurnal vertical migration ability of these species and their nutrient uptake in deep layers would make it possible for them to accumulate in the surface layer and form red tides in shallow coastal areas (Yamochi \& Abe 1984, Koizumi et al. 1996b). On the other hand, $C$. antiqua, $H$. circularisquama and $C$. polykrikoides can easily reach the warning level by consuming only small amounts of $\mathrm{N}$ and $\mathrm{P}$ (Table 4). We can 
Table 4. Warning level of cell densities of five representative red-tide organisms, minimum cell quota, and equivalent nutrient level to warning.

\begin{tabular}{|c|c|c|c|c|c|}
\hline \multirow{2}{*}{ Species } & \multirow{2}{*}{$\begin{array}{l}\text { Warning level } \\
\left(\text { cells } \mathrm{ml}^{-1}\right)\end{array}$} & \multicolumn{2}{|c|}{ Minimum cell quota $\left(\mathrm{fmol}\right.$ cell $\left.^{-1}\right)$} & \multirow{2}{*}{$\begin{array}{l}\mathrm{N}(\mu \mathrm{M}) \text { equivalent } \\
\text { to warning level }\end{array}$} & \multirow{2}{*}{$\begin{array}{c}\mathrm{P}(\mu \mathrm{M}) \text { equivalent } \\
\text { to warning level }\end{array}$} \\
\hline & & Nitrogen & Phosphorus & & \\
\hline Chattonella antiqua & 100 & 7800 & 620 & 0.78 & 0.062 \\
\hline Karenia mikimotoi & 5000 & 3130 & 250 & 15.7 & 1.25 \\
\hline Heterosigma akashiwo & 50000 & 1440 & 95 & 72.0 & 4.75 \\
\hline Heterocapsa circularisquama & 500 & 1100 & 89.4 & 0.55 & $0.045+$ \\
\hline Cochlodinium polykrikoides & 500 & 5250 & 370 & 2.63 & 0.185 \\
\hline
\end{tabular}

here conclude that $C$. antiqua, $H$. circularisquama and $C$. polykrikoides are extremely dangerous and harmful red-tide organisms. To prevent and/or reduce fishery damage by red tides, further developments of prediction techniques and mitigation strategies are important and urgent (Okaichi 1997, Imai et al. 2001).

\section{Toxic blooms}

Among the shellfish poisonings presented in Table 2, paralytic shellfish poisoning (PSP) and diarrhetic shellfish poisoning (DSP) have occurred in Japanese coastal waters (Fukuyo et al. 2002). DSP toxin contamination of marine shellfish such as scallops and oysters has commonly been detected off the coast of the Hokkaido and Tohoku districts. However, DSP toxin contamination has rarely been observed off the coast of western Japan despite the abundant existence of causative dinoflagellates of Dinophysis species such as $D$. fortii Pavillard and D. acuminata Claparède et Lachmann (Imai et al. 2003). This is an enigma to be solved in the future.

PSP contamination in bivalves was occasionally reported, mainly in short-necked clam, in the 1970s and 1980s (Fig. 8 ) in the Seto Inland Sea. The main causative organism was Alexandrium catenella (Whedon et Kofoid) Balech (Dinophyceae). However, in the 1990s and thereafter, toxic algal blooms and contamination of PSP toxins of bivalves have markedly increased in frequency and scale in the Seto Inland Sea and coastal areas of Kyushu and Shikoku of western Japan (Fig. 8) (Fukuyo et al. 2002, Kotani et al. 2004). The major causative organisms are Alexandrium tamarense (Lebour) Balech, A. catenella and Gymnodinium catenatum Graham (Dinophyceae). Alexandrium cysts play an important role in the occurrences of toxic blooms (Anderson 1998, Itakura \& Yamaguchi 2001). The common and abundant existence of Alexandrium (A. tamarense and $A$. catenella) cysts was confirmed in bottom sediments of the Seto Inland Sea and coastal areas of Kyushu and Shikoku (Yamaguchi et al. 1996, 2002, Kotani et al. 1998). Therefore, the problem of PSP toxin contamination of bivalves by Alexandrium spp. currently appears to have become established in these areas.

The population dynamics of $A$. tamarense was elaborately investigated in Hiroshima Bay, the Seto Inland Sea, from April 1994 to December 1998 (Itakura et al. 2002). PSP toxin contamination of bivalves has been occurring there almost every year since 1992. Vegetative cells of $A$. tamarense were detected from January to June, and annual maximum cell densities regularly reached $10^{3}-10^{4}$ cells $\mathrm{L}^{-1}$ in April or May every year. High germination success rates of Alexandrium cysts were observed between December and April each year (bottom water temperature $=10.0$ $16.5^{\circ} \mathrm{C}$ ), suggesting the importance of cysts in initiating Alexandrium (A. tamarense) blooms in Hiroshima Bay (Itakura \& Yamaguchi 2001). During the A. tamarense bloom period, the water temperature ranged from 10.2 to $20.2^{\circ} \mathrm{C}$, and $\mathrm{SiO}_{2}-\mathrm{Si}$ showed the annual lowermost concentration in each year during this period. The persistent yearly occurrence of vegetative cells of $A$. tamarense in Hiroshima Bay can be reasonably explained by temperature and nutrient conditions. The bloom of $A$. tamarense developed subsequently to the diatom spring bloom along with the exhaustion of $\mathrm{SiO}_{2}-\mathrm{Si}$ by diatoms. The origin of $A$. tamarense in western Japanese coastal areas after the 1990s is unknown at present, but there is a possibility that the introduction of bivalves from the northern part of Japan ( $A$. tamarense is common) was accompanied with cysts of $A$. tamarense (Furuhata et al. 1996) to the western Japanese coastal areas. Human activities can cause eutrophication of coastal waters and also help expand the distribution of harmful algal species to unaffected areas. More careful monitoring is needed in coastal environments.

\section{Prediction and mitigation of noxious red tides}

\section{Prediction of red tides}

The average economic loss associated with noxious red tides is around 1.5 billion yen per year; therefore, it is important to predict red-tide occurrences of noxious species killing fish and bivalves to reduce the negative impact on the aquaculture industry. The objectives of prediction are whether to expect the occurrence or not of red tides during the year, and the species, timing and period, area, and scale in the red-tide season. The prediction should be based on information obtained by scientific investigations about the mechanism of red-tide occurrence of each species. On the other hand, long-term predictions have been attempted using empirical relationships between red-tide occurrences 


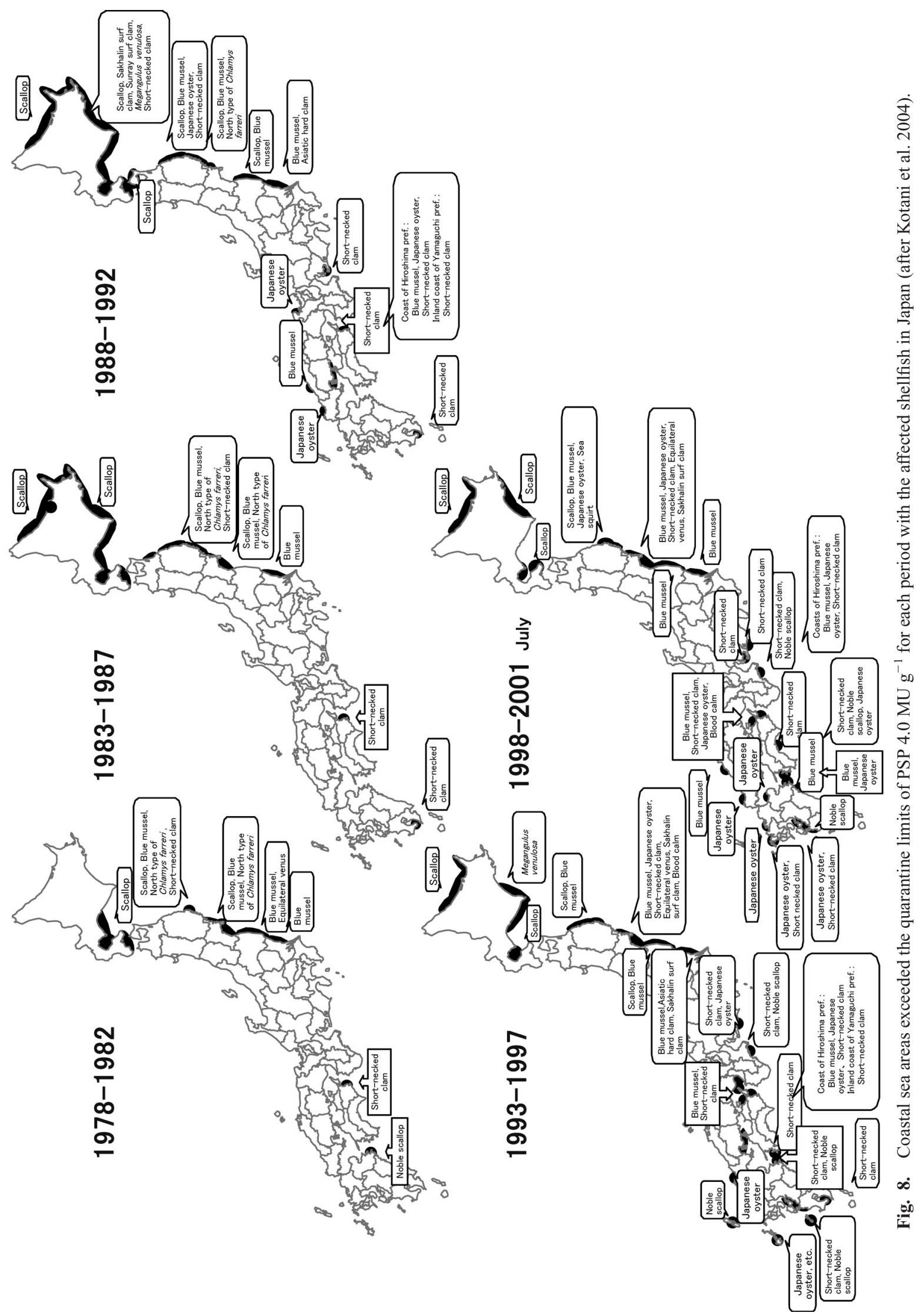


Table 5. Countermeasures for impact prevention and reduction of red tides attempted in Japan (after Shirota 1989 and Sakata 2000, modified).

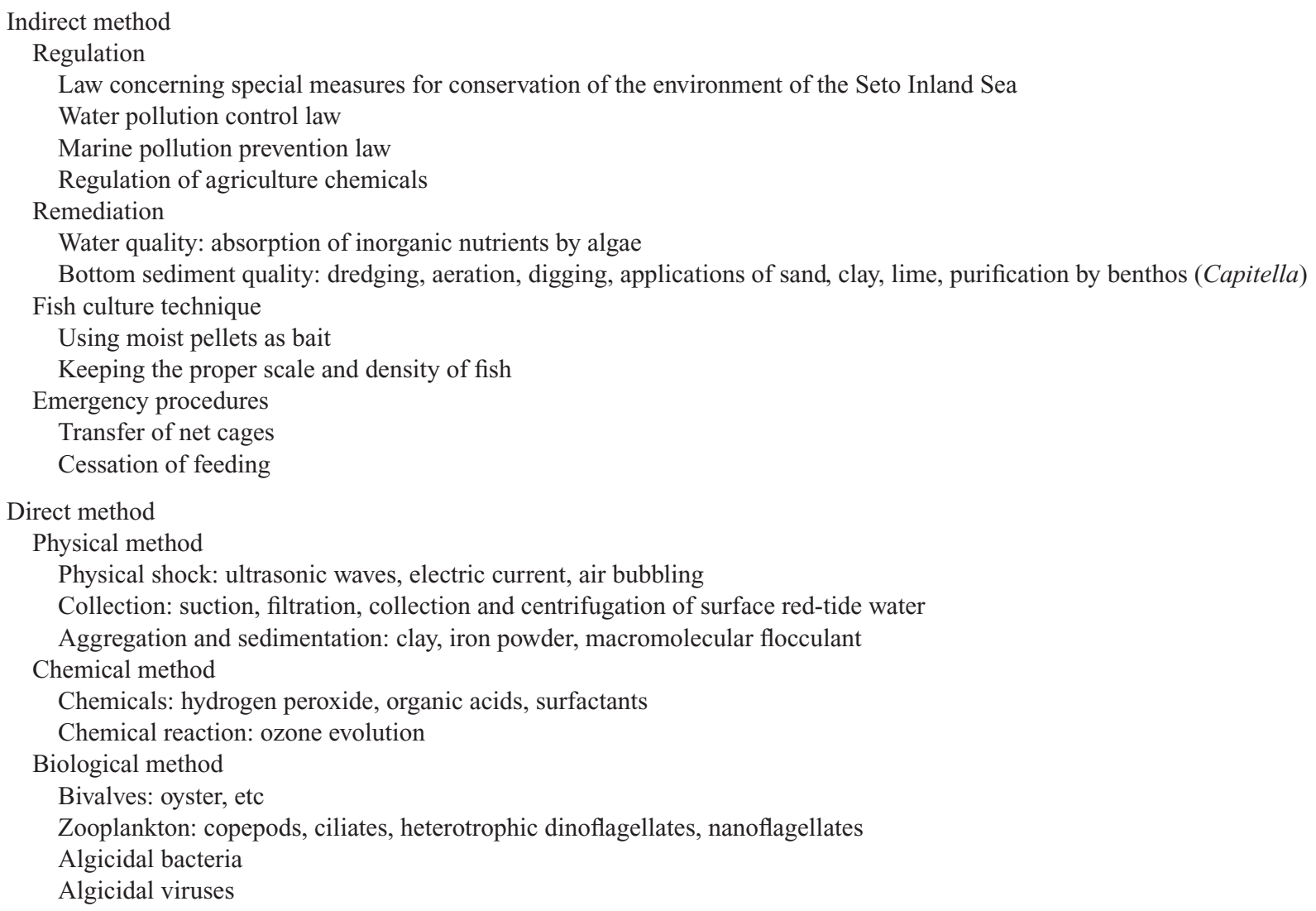

and field parameters such as west winds in winter, the distance of the Kuroshio Current, the water temperature and salinity in the Akashi Strait, etc. In the case of Chattonella red tides in Harima-Nada of the Seto Inland Sea, the prediction of occurrence was successful to some extent by combining results assessed using several parameters.

\section{Past countermeasures in Japan}

Table 5 represents previous countermeasures for noxious red tides attempted in Japan (after Shirota 1989 and Sakata 2000, modified). The countermeasures are roughly divided into two categories, indirect and direct methods. Indirect methods are basically significant for the prevention of redtide occurrences on a long-term scale. Laws were established for the environmental conservation in the coastal areas. Laws have been most effective for decreasing the direct discharge of polluted wastewater into the coastal sea. The resulting decreases of nitrogen and phosphorus in the water and sediments, as mentioned before, have led to a decrease in the incidents and scales of red tides. The development of fish culture techniques such as the "moist pellet" as a substitute for raw bait, keeping proper scale and density of fish in aquaculture sites, and transferring net cages from red-tide areas were also effective for reducing the negative impacts of noxious red tides. The most prevailing method is still to cease feeding cultured fish just before and during red tides, which reduces the mortality of fish in the cages, especially yellowtails.

As shown in Table 5, rather many direct methods had been attempted before 1985, but no physical and chemical controls were successful on the whole, as is the case for Florida's red tides in USA (Steidinger 1983). Thereafter, these chemical and physical control options have received little attention.

\section{Clay spraying to control red tides}

Shirota (1989) suggested one promising strategy that involves the treatment of red tides with flocculants such as clay, which scavenge particles including algal cells from seawater and carry them to bottom sediments. The feasibility of clay treatment has been investigated in Japan, China, South Korea, USA, Sweden and Australia (Kumamoto Prefecture 1980, Maruyama et al. 1987, Shirota 1989, Sengco \& Anderson 2004). In Japan and South Korea, clay spraying has already been employed to full implementation in aquaculture sites during red-tide occurrences, especially of Cochlodinium polykrikoides (Kim et al. 2002, Wada et al. 2002); however, further studies are essential to determine the fate and effects of sedimented microalgal cells and toxins on benthic animals and the collateral mortality of co-oc- 
curring planktonic organisms. The decomposition of sedimented biomass and resulting oxygen depletion also need to be examined (SCOR-IOC 1998).

\section{Biological control of red tides}

Chemical and physical controls of red tides are thought to have indiscriminant effects on all organisms in seawater. Biological controls are hoped to be milder and more environmentally friendly for exterminating red tides. The biological control of red tides using grazers such as copepods, bivalves and ciliates had been examined, but the results were minimal because of the huge scale of red tides (Shirota 1989). On the other hand, microorganisms such as viruses and bacteria appear to be promising control agents against red tides, as they can be abundant in marine ecosystems, proliferate rapidly, and are sometimes host-specific (SCOR-IOC 1998).

\section{Red tide control by viruses}

For some harmful algal bloom-causing species, infective viruses have been isolated and confirmed in laboratory cultures (Brussaard 2004, Salomon \& Imai 2006). In the case of red tides of Heterosigma akashiwo and Heterocapsa circularisquama, virus-induced mortality was demonstrated to be an important factor contributing to the rapid termination of red tides (Nagasaki et al. 1994, 2004). Viruses infectious to microalgae are usually host specific. Tomaru et al. $(2004 a, b)$ achieved gargantuan-scale investigations and found that viral infectivity can be strain specific rather than species specific in $H$. akashiwo and $H$. circularisquama. Accordingly, a single clone of algal virus can not exterminate a bloom of a specific microalgal species composed of different ecotypes of clones with different sensitivity spectra to viruses. However, viruses have extremely high replication ability and high host specificity (harmless to other organisms), and are consequently worth investigating for their possibility as a useful tool to prevent and exterminate harmful algal blooms.

\section{Red-tide control by algicidal bacteria}

During the last two decades, algicidal bacteria have been identified in marine coastal ecosystems and have received attention concerning the termination of noxious red tides (Imai et al. 1993a, Doucette et al. 1998, Sakata 2000, Yoshinaga 2002, Mayali \& Azam 2004, Salomon \& Imai 2006). Temporal fluctuations of algicidal bacteria against the red tide causing raphidophyte Heterosigma akashiwo were studied in northern Hiroshima Bay, the Seto Inland Sea, and the dynamics of $H$. akashiwo killers revealed a close relationship with that of $H$. akashiwo populations (Imai et al. 1998a, Yoshinaga et al. 1998). These results indicate that algicidal bacteria (mainly members of $\gamma$-proteobacteria) are specifically associated with the termination of H. akashiwo red tides (Yoshinaga et al. 1998). In the case of population dynamics of Chattonella spp. and the algicidal bacterium Cytophaga sp. in northern Harima-Nada, this bacterium also increased, accompanying the decline of Chattonella populations (Imai et al. 2001). Accordingly, algicidal bacteria presumably contribute to the rapid termination of red tides in coastal seas.

Many strains of algicidal bacteria have been isolated from various sites of Japanese coastal seas (Yoshinaga 2002). These bacteria were classified phylogenetically using the SSU rDNA database. Many algicidal bacteria are new species. Most algicidal bacteria are categorized into two groups, $\gamma$-proteobacteria (mainly the genera $\mathrm{Al}$ teromonas and Pseudoalteromonas) and Cytophaga/Flexibacter/Bacteroides (CFB) group (mainly the genus $\mathrm{Cy}$ tophaga) (Yoshinaga 2002, Mayali \& Azam 2004), and a few are $\gamma$-proteobacteria (Imai et al. in press).

\section{Seaweed beds: possible prevention strategies for red tides}

As an unexpected aspect of the ecology of algicidal bacteria, it has newly been found that huge numbers of algicidal bacteria are attached to the surface of seaweeds such as Ulva sp. (Chlorophyta) and Gelidium sp. (Rhodophyta) (Imai et al. 2002). The maximum number of killers, about $10^{5}-10^{6} \mathrm{~g}^{-1}$ (wet weight of seaweed), was detected for Karenia mikimotoi, Fibrocapsa japonica and Heterosigma akashiwo. Algicidal bacteria were also abundant in seawater collected in seaweed beds in Osaka Bay and Obama Bay. Algicidal bacteria were isolated from the surface of Ulva sp. and Gelidium sp. and surrounding seawater (Imai et al. in press). This indicates the potential of seaweed beds and surrounding seawater to prevent red-tide occurrences by the killing function of algicidal bacteria continually released from the surface of seaweeds (Fig. 9).

Based on these findings, we can here propose a new prevention strategy of red tides using macroalgae in aquaculture areas. Co-culturing seaweeds such as Gelidium sp. and/or Ulva sp. and fish such as red sea bream or yellowtail is proposed to be effective in cage cultures (Imai et al. 2002). Many algicidal bacteria will be continually released from the surface of macroalgae into seawater, and contribute to reduce the cell density of phytoplankton, including harmful species. Consequently, these bacteria presumably play an important role in preventing the occurrence of noxious red tides. This strategy may be effective in en-

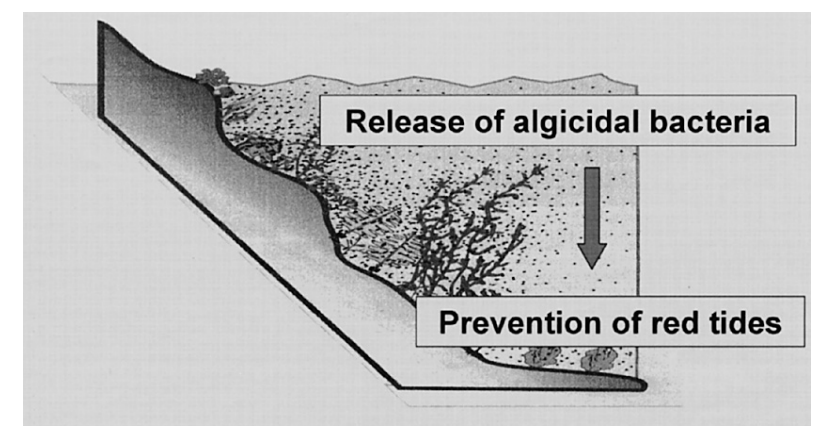

Fig. 9. Seaweed beds as sources of algicidal bacteria that help prevent the occurrences of red tides in coastal areas. 
closed and small-scale inlets. The most excellent merit of this strategy is that seaweed has no negative image for aquaculture fishermen and consumers. Moreover, Ulva sp. is actually being utilized as supplementary food for red sea breams in some cage cultures in Mie and Ehime Prefectures in Japan.

When we artificially develop and restore natural seaweed beds in a large-scale plan, which have been lost in the past by reclamation, these newly recovered seaweed beds presumably function as tools to prevent the occurrence of harmful algal blooms by virtue of released algicidal bacteria (Fig. 9). Furthermore, seaweed beds also serve as purifying grounds of seawater by the absorption of inorganic nutrients and as nursery grounds for important fishery resources such as fish and invertebrates. It appears to be worth investigating and discussing the implementation of the artificial development or restoration of seaweed beds around red-tide areas in the near future.

\section{Future problems in the mitigation and control of red tides}

No field trials of bloom control using viruses and algicidal bacteria have been attempted previously. Uncertainties about host specificity, stability, and environmental impacts such as the negative effects of these microorganisms on higher organisms must be examined before their practical utilization as tools for the prevention and control of noxious red-tide occurrences. Costs and scales should also be considered for in situ implementation.

When algicidal viruses and bacteria terminate red tides, huge amounts of organic matter would be released into water environments. The resulting organic matter must enter the marine food web mainly via microbial food web components (Kamiyama et al. 2000). If not, such released organic materials would most likely cause deterioration of the coastal environment, especially the bottom layer through e.g. anoxia. The fate of algicidal bacteria and viruses such as grazing by protozoans should be investigated after the termination of red tides by these microorganisms. Studies on the ecology of the algicidal bacteria and viruses with harmful algae should take into account trophic interactions in the marine food web.

\section{Acknowledgements}

We are grateful to Dr. Yuichi Kotani, National Research Institute of Fisheries Science, Dr. S. Itakura, National Research Institute of Fisheries and Environments of Inland Sea, and Mr. T. Nishikawa, Fisheries Technology Institute, Hyogo Prefectural Technology Center for Agriculture, Forestry and Fisheries, for their cooperation in preparing this manuscript. This article was supported in part by a grant from the Fisheries Agency of Japan and also by a grant-in-aid for scientific research (No. 16380131) from the Ministry of Education, Science, and Culture, Japan.

\section{References}

Anderson DM (1998) Physiology and bloom dynamics of toxic Alexandrium species, with emphasis on life cycle transitions. In: Physiological Ecology of Harmful Algal Blooms (eds Anderson DM, Cembella AD, Hallegraeff GM). Springer, Berlin, pp. 29-48.

Brussaard CPD (2004) Viral control of phytoplankton populations - a review. J Eukaryot Microbiol 51: 125-138.

Doucette GJ, Kodama M, Franca S, Gallacher S (1998) Bacterial interactions with harmful algal bloom species: Bloom ecology, toxigenesis, and cytology. In: Physiological Ecology of Harmful Algal Blooms (eds Anderson DM, Cembella AD, Hallegraeff GM). Springer, Berlin, pp. 619-647.

Fisheries Agency (2000) Red Tides in the Seto Inland Sea and Fisheries Damage (1970-1998). 112 pp. (in Japanese)

Fisheries Agency (2005) Red Tides in the Seto Inland Sea (2004). 70 pp. (in Japanese)

Fukuyo Y, Imai I, Kodama M, Tamai K (2002) Red tides and other harmful algal blooms in Japan. In: Harmful Algal Blooms in the PICES Region of the North Pacific, PICES Scientific Report No. 23 (eds Max-Taylor FJR, Trainer VL). Institute of Ocean Sciences, Sidney, Canada, pp. 7-20.

Furuhata K, Kakino J, Miyama Y, Fukuyo Y (1996) Elimination of cysts of the toxic dinoflagellates Alexandrium spp. contaminated in hard clam. Nippon Suisan Gakkaishi 62: 813-814. (in Japanese with English abstract)

Hallegraeff G (1993) A review of harmful algal blooms and their apparent global increase. Phycologia 32: 79-99.

Hiroshima Prefecture (1996) Manual on Countermeasures for Red Tides in Hiroshima Prefecture. 55 pp. (in Japanese)

Honjo T (1992) Harmful red tides of Heterosigma akashiwo. NOAA Technical Report NMFS 111: 27-32.

Honjo T, Imada N, Oshima Y, Maema Y, Nagai K, Matsuyama Y, Uchida T (1998) Potential transfer of Heterocapsa circularisquama with pearl oyster consignments. In: Harmful Algae (eds Reguera B, Blanco J, Fernandez ML, Wyatt T). Xunta de Galicia and IOC of UNESCO, Vigo, pp. 224-226.

Imai I, Fujimaru D, Nishigaki T (2002) Co-culture of fish with macroalgae and associated bacteria: A possible mitigation strategy for noxious red tides in enclosed coastal sea. Fisheries Sci 68 (Supplement): 493-496.

Imai I, Fujimaru D, Nishigaki T, Kurosaki M, Sugita H (2006) Algicidal bacteria against harmful microalgae isolated from the surface of seaweeds in the coast of Osaka Bay, Seto Inland Sea, Japan. Afr J Mar Sci 28: in press.

Imai I, Ishida Y, Hata Y (1993a) Killing of marine phytoplankton by a gliding bacterium Cytophaga sp., isolated from the coastal sea of Japan. Mar Biol 116: 527-532.

Imai I, Itakura S (1999) Importance of cysts in the population dynamics of the red tide flagellate Heterosigma akashiwo (Raphidophyceae). Mar Biol 133: 755-762.

Imai I, Itakura S, Itoh K (1993b) Cysts of the red tide flagellate Heterosigma akashiwo, Raphidophyceae, found in bottom sediments of northern Hiroshima Bay, Japan. Nippon Suisan Gakkaishi 59: 1669-1673.

Imai I, Itoh K (1986) A preliminary note on the cysts of Chattonella (Raphidophyceae), red tide flagellates, found in bottom 
sediment in Suo-Nada, western Seto Inland Sea, Japan. Bull Plankton Soc Japan 33: 61-63. (in Japanese with English abstract)

Imai I, Itoh K (1987) Annual life cycle of Chattonella spp., causative flagellates of noxious red tides in the Inland Sea of Japan. Mar Biol 94: 287-292.

Imai I, Itoh K (1988) Cysts of Chattonella antiqua and C. marina (Raphidophyceae) in sediments of the Inland Sea of Japan. Bull Plankton Soc Japan 35: 35-44.

Imai I, Kim MC, Nagasaki K, Itakura S, Ishida Y (1998a) Relationships between dynamics of red tide-causing raphidophycean flagellates and algicidal micro-organisms in the coastal sea of Japan. Phycol Res 46: 139-146.

Imai I, Sugioka H, Nishitani G, Mitsuya T, Hamano Y (2003) Monitoring of DSP toxins in small-sized plankton fraction of seawater collected in Mutsu Bay, Japan, by ELISA method: relation with toxin contamination of scallop. Mar Poll Bull 47: 114-117.

Imai I, Sunahara T, Nishikawa T, Hori Y, Kondo R, Hiroishi S (2001) Fluctuations of the red tide flagellates Chattonella spp. (Raphidophyceae) and the algicidal bacterium Cytophaga sp. in the Seto Inland Sea. Mar Biol 138: 1043-1049.

Imai I, Yamaguchi M, Watanabe M (1998b) Ecophysiology, life cycle, and bloom dynamics of Chattonella in the Seto Inland Sea, Japan. In: Physiological Ecology of Harmful Algal Blooms (eds Anderson DM, Cembella AD, Hallegraeff GM). Springer, Berlin, pp. 95-112.

Itakura S, Yamaguchi M (2001) Germination characteristics of naturally occurring cysts of Alexandrium tamarense (Dinophyceae) in Hiroshima Bay, Inland Sea of Japan. Phycologia 40: 263-267.

Itakura S, Yamaguchi M, Yoshida M, Fukuyo Y (2002) The seasonal occurrence of Alexandrium tamarense (Dinophyceae) vegetative cells in Hiroshima Bay, Japan. Fisheries Sci 68: $77-86$.

Iwasaki H (1989) Recent progress of red tide studies in Japan: An overview. In: Red Tides: Biology, Environmental Science, and Toxicology (eds Okaichi T, Anderson DM, Nemoto T). Elsevier, Amsterdam, pp. 3-9.

Iwataki M, Wong MW, Fukuyo Y (2002) New record of Heterocapsa circularisquama (Dinophyceae) from Hong Kong. Fisheries Sci 68: 1161-1163.

Kamiyama T, Itakura S, Nagasaki K (2000) Changes in microbial loop components: effects of a harmful algal bloom formation and its decay. Aquat Microb Ecol 21: 21-30.

Kim DI (2003) Physiological and Ecological Studies on Harmful Red Tide Dinoflagellate Cochlodinium polykrikoides (Margalef). Doctoral dissertation, Kyushu University, Fukuoka, 154 pp. (in Japanese)

Kim DI, Matsuyama Y, Nagasoe S, Yamaguchi M, Yoon YH, Oshima Y, Imada N, Honjo T (2004) Effects of temperature, salinity and irradiance on the growth of the harmful red tide dinoflagellate Cochlodinium polykrikoides Margalef (Dinophyceae). J Plankton Res 26: 61-66.

Kim HG, Lee SG, Jeong CS, Bae HM (2002) Current situation of harmful algal blooms and mitigation strategies in Korean coastal waters. In: Prevention and Extermination Startegies of Harmful Algal Blooms (eds Hiroishi S, Imai I, Ishimaru T).
Koseisha-kouseikaku, Tokyo, pp. 134-150. (in Japanese)

Koizumi Y, Kohno J, Matsuyama Y, Uchida T, Honjo T (1996a) Environmental features and the mass mortality of fish and shellfish during the Gonyaulax polygramma red tide occurred in and around Uwajima bay, Japan, in 1994. Nippon Suisan Gakkaishi 62: 217-224. (in Japanese with English abstract)

Koizumi Y, Uchida T, Honjo T (1996b) Diurnal vertical migration of Gymnodinium mikimotoi during a red tide in Hoketsu Bay, Japan. J Plankton Res 18: 289-294.

Kotani Y, Koyama A, Yamaguchi M, Imai I (1998) Distribution of resting cysts of the toxic dinoflagellates Alexandrium catenella and/or A. tamarense in the coastal areas of western Shikoku and Kyushu, Japan. Bull Jpn Soc Fish Oceanogr 62: 104-111. (in Japanese with English abstract)

Kotani Y, Tamai K, Yamaguchi M, Okubo S, Matui K, Nakamura $\mathrm{T}$ (2004) Historical and current status of red tides and shellfish poisonings in Japan. In: Harmful Algae Management and Mitigation (eds Hall S, Etheridge S, Anderson DM, Kleindinst J, Zhu M, Zou Y). APEC Publication, Singapore, pp. 25-33.

Kumamoto Prefecture (1980) The annual report for the developments of countermeasures to red tides (1979): Examination of clay spraying for flocculation of red tides. $43 \mathrm{pp}$. (in Japanese)

Manabe T, Ishio S (1991) Bloom of Coscinodiscus wailesii and DO deficit of bloom water in Seto Inland Sea. Mar Poll Bull 23: 181-184.

Manabe T, Tanda M, Hori Y, Nagai S, Nakamura Y (1994) Changes in eutrophication and phytoplankton in HarimaNada-Results of environmental monitoring for 20 yearsBull Coast Oceanogr 31: 169-181. (in Japanese with English abstract)

Maruyama T, Yamada R, Usui K, Suzuki H \& Yoshida T (1987) Removal of marine red tide plankton with acid-treated clay. Nippon Suisan Gakkaishi 53: 1811-1819. (in Japanese with English abstract)

Matsuoka K, Iwataki M (2004) Present status in study on a harmful unarmored dinoflagellate Cochlodinium polykrikoides Margalef. Bull Plankton Soc Japan 51: 38-45. (in Japanese with English abstract)

Matsuyama Y (1999) Harmful effect of dinoflagellate Heterocapsa circularisquama on shellfish aquaculture in Japan. JARQ 33: 283-293.

Mayali X, Azam F (2004) Algicidal bacteria in the sea and their impact on algal blooms. J Eukaryot Microbiol 51: 139-144.

Ministry of the Environment Government of Japan \& the Association for the Environmental Conservation of the Seto Inland Sea (2001) The Seto Inland Sea-The Largest Enclosed Coastal Sea in Japan. 35pp.

Miyahara K, Uji R, Yamada H, Matsui Y, Nishikawa T, Onitsuka G (2005) A harmful algal bloom of Cochlodinium polykrikoides Margalef (Dinophyceae) in the coastal area of San-in, western part of the Japan Sea, in September 2003. Bull Plankton Soc Japan 52: 11-18. (in Japanese with English abstract)

Montani S (2000) Ecological approaches to environmental management in fishing farm. In: Mechanisms, Prediction, and Mitigation of Harmful Algal Blooms in Japan (eds Ishida Y, Honjo T, Fukuyo Y, Imai I). The Japan Fisheries Resource Conservation Association, Tokyo, pp. 236-256. (in Japanese)

Nagai S (2000) Occurrence mechanisms and prediction of the 
blooms of a giant diatom Coscinodiscus wailesii. In: Mechanisms, Prediction, and Mitigation of Harmful Algal Blooms in Japan (eds Ishida Y, Honjo T, Fukuyo Y, Imai I). The Japan Fisheries Resource Conservation Association, Tokyo, pp. 71-100. (in Japanese)

Nagasaki K, Ando M, Itakura S, Imai I, Ishida Y (1994) Viral mortality in the final stage of Heterosigma akashiwo (Raphidophyceae) red tide. J Plankton Res 16: 1595-1599.

Nagasaki K, Tomaru Y, Nakanishi K, Hata N, Katanozaka N, Yamaguchi M (2004) Dynamics of Heterocapsa circularisquama (Dinophyceae) and its virus in Ago Bay, Japan. Aquat Microb Ecol 34: 219-226.

Okaichi T (1997) Red tides in the Seto Inland Sea. In: Sustainable Development in the Seto Inland Sea, Japan-From the Viewpoint of Fisheries (eds Okaichi T, Yanagi T). Terra Scientific Publishing Company, Tokyo, pp. 251-304.

Sakata T (2000) Control of harmful microalgae by microorganisms. In: Mechanisms, Prediction, and Mitigation of Harmful Algal Blooms in Japan (eds Ishida Y, Honjo T, Fukuyo Y, Imai I). The Japan Fisheries Resource Conservation Association, Tokyo, pp. 215-235. (in Japanese)

Salomon PS, Imai I (2006) Pathogens of harmful algae. In: Ecology of Harmful Algae (eds Edna G, Turner JT). Springer, Berlin, in press.

SCOR-IOC (1998) The Global Ecology and Oceanography of Harmful Algal Blooms-A Plan for Coordinated Scientific Research and Co-operation to Develop International Capabilities for Assessment, Prediction and Mitigation. Report from a Joint IOC/SCOR Workshop, Havreholm, Denmark. 43 pp.

Sengco MR, Anderson DM (2004) Controlling harmful algal blooms through clay flocculation. J Eukaryot Microbiol 51: 169-172.

Shirota A (1989) Red tide problem and countermeasures (2). Int J Aquat Fish Technol 1: 195-223.

Smayda TJ (1998) Ecophysiology and bloom dynamics of Heterosigma akashiwo (Raphidophyceae). In: Physiological Ecology of Harmful Algal Blooms (eds Anderson DM, Cembella AD, Hallegraeff GM). Springer, Berlin, pp. 113-131.

Smayda TJ (2002) Adaptive ecology, growth strategies and the global bloom expansion of dinoflagellates. J Oceanogr 58: 281-294.

Steidinger KA (1983) A re-evaluation of toxic dinoflagellate biology and ecology. In: Progress in Phycological Research, vol. 2 (eds Round FE, Chapman DG). Elsevier, B. V., pp. 147-188.

Tamai K (1999) Current status of outbreaks and fisheries damages due to Heterocapsa circularisquama. Bull Plankton Soc Japan 46: 153-154. (in Japanese with English abstract)

Tomaru Y, Katanozaka N, Nishida K, Shirai Y, Tarutani K, Yamaguchi M, Nagasaki K (2004a) Isolation and characterization of two distinct types of HcRNAV, a single-stranded RNA virus infecting the bivalve-killing microalga Heterocapsa circularisquama. Aquat Microb Ecol 34: 207-218.

Tomaru Y, Tarutani K, Yamaguchi M, Nagasaki K (2004b) Quantitative and qualitative impacts of viral infection on a Heterosigma akashiwo bloom in Hiroshima Bay, Japan. Aquat Microb Ecol 34: 227-238.

Wada M, Nakashima M, Maeda H (2002) Red tide extermination by the clay spraying. In: Prevention and Extermination Starte- gies of Harmful Algal Blooms (eds Hiroishi S, Imai I, Ishimaru T). Koseisha-kouseikaku, Tokyo, pp. 121-133. (in Japanese)

Yamaguchi M, Itakura S, Imai I, Ishida Y (1995) A rapid and precise technique for enumeration of resting cysts of Alexandrium spp. (Dinophyceae) in natural sediments. Phycologia 34: 207-214.

Yamaguchi M, Itakura S, Nagasaki K, Imai I (1996) Distribution and abundance of resting cysts of the toxic dinoflagellates Alexandrium tamarense and A. catenella in sediments of the eastern Seto Inland Sea, Japan. In: Harmful and Toxic Algal Blooms (eds Yasumoto T, Oshima Y, Fukuyo Y). IOC-UNESCO, Paris, pp.177-180.

Yamaguchi M, Itakura S, Nagasaki K, Kotani Y (2002) Distribution and abundance of resting cysts of the toxic Alexandrium spp. (Dinophyceae) in sediments of the western Seto Inland Sea, Japan. Fisheries Sci 68: 1012-1019.

Yamaguchi M, Itakura S, Nagasaki K, Matsuyama Y, Uchida T, Imai I (1997) Effects of temperature and salinity on the growth of the red tide flagellates Heterocapsa circularisquama (Dinophyceae) and Chattonella verruculosa (Raphidophyceae). J Plankton Res 19: 1167-1174.

Yamaguchi M, Itakura S, Uchida T (2001) Nutrition and growth kinetics in nitrogen- or phosphorus-limited cultures of the 'novel red tide' dinoflagellate Heterocapsa circularisquama (Dinophyceae). Phycologia 40: 313-318.

Yamatogi T, Sakaguti M, Takagi N, Iwataki M, Matsuoka K (2005) Effects of temperature, salinity and light intensity on the growth of a harmful dinoflagellate Cochlodinium polykrikoides Margalef occurring in coastal waters of West Kyushu, Japan. Bull Plankton Soc Japan 52: 4-10. (in Japanese with English abstract)

Yamatogi T, Sakaguchi M, Iwataki M, Matsuoka K (2006) Effects of temperature and salinity on the growth of four harmful red tide flagellates occurring in Isahaya Bay in Ariake Sound, Japan. Nippon Suisan Gakkaishi 72: 160-168. (in Japanese with English abstract)

Yamochi S, Abe T (1984) Mechanism to initiate a Heterosigma akashiwo red tide in Osaka Bay II. Diel vertical migration. Mar Biol 83: 255-261.

Yoon YH (2001) A summary on the red tide mechanisms of the harmful dinoflagellate, Cochlodinium polykrikoides in Korean coastal waters. Bull Plankton Soc Japan 48: 113-120. (in Japanese with English abstract)

Yoshinaga I (2002) Extermination of harmful algal blooms by algicidal bacteria. In: Prevention and Extermination Startegies of Harmful Algal Blooms (eds Hiroishi S, Imai I, Ishimaru T). Koseisha-kouseikaku, Tokyo, pp. 63-80. (in Japanese)

Yoshinaga I, Kim MC, Katanozaka N, Imai I, Uchida A, Ishida Y (1998) Population structure of algicidal marine bacteria targeting the red tide forming alga Heterosigma akashiwo (Raphidophyceae), determined by restriction fragmental length polymorphism analysis of the bacterial $16 \mathrm{~S}$ ribosomal RNA genes. Mar Ecol Prog Ser 170: 33-44.

Yuki K, Yoshimatsu S (1989) Two fish-killing species of Cochlodinium from Harima Nada, Seto Inland Sea, Japan. In: Red Tides: Biology, Environmental Science, and Toxicology (eds Okaichi T, Anderson DM, Nemoto T). Elsevier, NY, pp. 451-454. 